\title{
The influence of Alpine soil properties on shallow movement hazards, investigated through factor analysis
}

\author{
S. Stanchi ${ }^{1,2}$, M. Freppaz ${ }^{1,2}$, and E. Zanini ${ }^{1,2}$ \\ ${ }^{1}$ Università di Torino, DIVAPRA - Chimica Agraria e Pedologia, Via L. Da Vinci 44, 10095 Grugliasco (TO), Italy \\ ${ }^{2}$ Research Centre on Natural Risks in Mountain and Hilly Environments, 10095 Grugliasco (TO), Italy \\ Correspondence to: S. Stanchi (silvia.stanchi@unito.it)
}

Received: 26 October 2011 - Revised: 21 January 2012 - Accepted: 19 February 2012 - Published: 12 June 2012

\begin{abstract}
Mountain watersheds are particularly vulnerable to extreme meteorological events, such as high intensity rainfall, and mountain soils often show pronounced fragility and low resilience due to severe environmental conditions. Alpine soil vulnerability is partly intrinsic but in part related to climate change (mainly precipitation regimes), and is enhanced by the abandonment of rural mountain areas that reduced the land maintenance actions traditionally carried out by farmers and local populations in the past. Soil hazards are related to different processes such as water erosion, loss of consistency, surface runoff and sediment transport, often occurring simultaneously and interacting with each other. Therefore, the overall effects on soil are not easy to quantify as they can be evaluated from different soil chemical and physical properties, referring to specific soil loss phenomena such as soil erosion, soil liquefaction, loss of consistency etc. In this study, we focus our attention on a mountain region in the NW Italian Alps (Valle d'Aosta), which suffered from diffuse soil instability phenomena in recent years, as a consequence of extreme rainfall events and general abandonment of the agricultural activities in marginal areas. The main effects were a large number of shallow landislides involving limited soil depths (less than $1 \mathrm{~m}$ ), affecting considerable surfaces in the lower and middle part of the slopes. These events caused loss of human lives in the year 2000 and therefore raised the attention on land maintenance issues. Surface (topsoil: $0-20 \mathrm{~cm}$ ) and subsurface (subsoil: $20-70 \mathrm{~cm}$ ) samples were characterised chemically and physically $(\mathrm{pH}$, carbon and nitrogen contents, cation exchange capacity, texture, aggregate stability, Atterberg limits etc.) and they showed very different soil properties. Topsoils were characterised by better stability, structure, and consistency. The differences between the two depths were potential trigger factors for shallow soil movements involving the upper
\end{abstract}

soil horizons. We assessed a great number of soil properties that are known to be related to vulnerability to the main hazards present in the area. These properties were evaluated at the two depths and a factor analysis was performed to simplify the dataset interpretation, and to hypothesise the most decisive parameters that were potentially related to vulnerability. The factors (soil structure, aggregation, consistency, texture and parent material, cation exchange complex and other chemical properties) were a first step towards identifying soil quality indexes in the studied environment.

\section{Introduction}

Mountain watersheds are particularly vulnerable to extreme rainfall events (Giannecchini et al., 2007; Turconi et al., 2010), which may trigger shallow soil movements, involving limited soil depths (Giannecchini, 2005) and diffuse erosion. This is particularly evident in the Alps, where the increased occurrence of extreme precipitation events has been observed as a result of climate change (IPCC, 2007; Lindner et al., 2010). Besides this, the marginalization of mountain areas can enhance the natural hazard frequency as the land maintenance is less capillary and large agricultural areas have been abandoned.

Mountain soils are also characterised by intrinsic fragility (Sanchez-Maranon et al., 2002; Descroix and Gautier, 2002; Arnaud-Fassetta et al., 2004; Alewell et al., 2008; Stanchi et al., 2009) and low resilience (i.e. the capability to recover after severe stresses, Seybold et al., 1999), making them almost non-renewable. Even if the soils of the alpine areas have profiles that are very irregular with regards, for example, to thickness of horizon or depth to bedrock, generally they have considerable skeleton content, and coarse 
texture with sand and silt abundance. Extreme climatic conditions limit the soil profile evolution and the differentiation of diagnostic horizons. Also soil erosion contributes to the scarce profile development, as surface material is continuously transported by runoff. The main factors driving soil development are climate and relief. Soil losses for erosion may be very high depending on site variables such as slope, vegetation cover, and parent material (Egli et al., 2001; Khormali et al., 2009). Descroix and Mathys (2003, French South Alps) observed that erosion losses are 2 to 3 orders of magnitude higher on bare soils than on pastures. However, alpine soils are fragile also in terms of physical properties such as soil structure and consistency that can be potentially lost after extreme rainfall events (Crosta et al., 2003; Luino, 2005) or wet snow avalanches (Freppaz et al., 2010, Confortola et al., 2012). Soil losses can be related to different morphological processes acting at slope and watershed scales (Bell and Glade, 2004; Luino, 2005), such as soil slips, debris flows, solifluctions, and diffuse erosion. The susceptibility to all these phenomena is difficult to assess, as the triggering factors, occurrence thresholds and mechanisms are complex. Moreover, soil properties usually show high variability in all spatial dimensions, i.e. both in their spatial distribution on the slope and along the soil profile, with discontinuities in soil properties. Despite these limitations, some chemical and physical properties are known to be related to soil losses, when extreme rainfall events occur (Luino, 2005; Stanchi et al., 2008b).

Soil quality indicators have been often proposed as sets of soil properties (physical, chemical, biological) that are able to change abruptly after changes in soil use and management or disturbances (Brejda et al., 2000; Ajami et al., 2006), and therefore also assess the level of soil degradation. As remarked by Karlen et al. (1997), the choice of quality indicators (such as the ones proposed by Shukla et al., 2006) depends on the observer's focus (e.g. agriculture and crop production, land management and conservation, engineering, environmental protection etc.). In mountain environments, soil quality depends strongly on soil structure and consistency conservation.

Assessing soil intrinsic vulnerability to loss phenomena through soil quality indicators would be a fundamental step forward in land use planning. No standardised set of indicators is available to evaluate soil vulnerability in mountain areas, and this is partly justified by the relative scarcity of soil data in mountain environments. Factor analysis is commonly used to identify underlying patterns in soil properties of environmental interests (Donkin and Fay, 1991; Pardini et al., 2004), i.e. finding factors behaving as "hidden variables" from a larger set of correlated variables. In this case, we are looking for a number of not immediately measurable factors that are responsible for soil vulnerability, using a larger number of more easily measurable variables that are known or likely to be related to soil vulnerability.

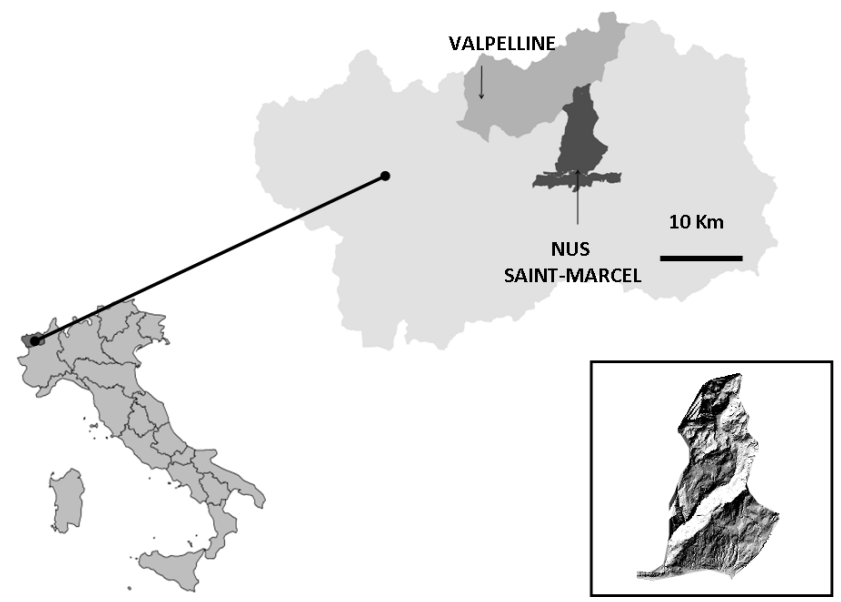

Fig. 1. Location of the study area with the two subareas in Italy.

In previous research (Stanchi et al., 2008b, 2009) we studied the properties of topsoil and subsoil of a limited pilot area located in the Aosta Valley (NW Italian Alps). In this work we focused our attention on a larger dataset from a wider area in the same Region (Fig. 1), often affected by shallow soil movements (upper decimetres of soil) with different mechanisms. Soil vulnerability was studied at two depths (topsoil: 0-20 cm, corresponding to A horizons, i.e. surface horizons richer in organic matter and generally characterised by more pronounced aggregation, largely related to root presence and with relatively abundant soil fauna activity; subsoil: 20-70 cm, corresponding to AC (with properties inherited by the parent material) or Bw (with incipient alteration, diagnostic for Inceptisols) horizons, characterised by lower organic matter content than the topsoil and more related to pedogenic processes). These depths are often involved in shallow soil movements and soil losses in the study areas.

Some of the chemical and physical properties related to surface soil losses were studied, and factor analysis was performed in order to individuate and interpret the main factors describing soil vulnerability in the studied environment. This assessment may help in further studying the thresholds of shallow soil instability phenomena registered in the study area.

\section{Study areas and methods}

\subsection{Study areas}

Two study areas were chosen in the Aosta Valley (Fig. 1), which were particularly subject to soil loss and instability phenomena, and have been monitored and documented in recent years (Nus-Saint Marcel and Valpelline), particularly after the year 2000 when an extreme rainfall event caused a big flooding. The study areas are representative of the regions environmental characteristics, and types and frequency 
Table 1. Main characteristics of the study areas.

\begin{tabular}{lll}
\hline & Valpelline & $\begin{array}{l}\text { Nus } \\
\text { Saint-Marcel }\end{array}$ \\
\hline Area $\left(\mathrm{km}^{2}\right)$ & 465 & 82 \\
Altitude range (m a.s.l.) & $800-4150$ & $500-3500$ \\
Main vegetation typologies & $\begin{array}{l}\text { Larix decidua, Picea excelsa, Pinus cembra, } \\
\text { mixed broadleaved forest, alpine grassland, } \\
\text { agricultural areas }\end{array}$ & $\begin{array}{l}\text { broadleaved forests, alpine grassland, agricul- } \\
\text { tural areas }\end{array}$ \\
Main geological covers & $\begin{array}{l}\text { Dioritic formations and (upper part); moraines, } \\
\text { taluses, debris }\end{array}$ & $\begin{array}{l}\text { Alluvial deposits, moraines and debris, preva- } \\
\text { lence of mixed lithologies }\end{array}$ \\
Main natural hazard typologies & Landslides, soil slips; surface erosion & $\begin{array}{l}\text { Landslides, solid transport; wildfires; soil slips, } \\
\text { debris flows, surface erosion }\end{array}$ \\
\hline
\end{tabular}

of natural hazards. The climate is characterised by dryness (mean annual precipitation $580 \mathrm{~mm}$ ), as characteristic for the inner part of the Valley (Filippa et al., 2010), with extreme rainfall events particularly frequent during spring and autumn. The information about environmental variables (climate, geology, vegetation) were given by the Valle d'Aosta Region as printed maps or shapefiles. Table 1 collects the main information on the 2 study sites.

\subsubsection{Valpelline subarea}

The Valpelline subarea has a surface of $465 \mathrm{~km}^{2}$. It includes the Buthier watershed, and reaches from 800 to $4150 \mathrm{~m}$ a.s.l. The upper part of the valley is characterised by dioritic formations, the lower part by gneiss of the Arolla series. Most of the Quaternary cover is formed by moraines, taluses and debris, partly by big boulders. Wide areas are affected by landslides involving detritus and moraines. Alluvial deposits are present along the main hydrological network. The forest cover is dominated by Larix decidua and Picea excelsa, associated with Pinus cembra at higher or Pinus sylvestris at lower elevations. Larix decidua and Pinus sylvestris dominate in sun-exposed slopes. Broadleaved mixed forests progressively substitute coniferous species as the altitude decreases. Herbaceous cover ranges from grasslands-orchards in the lower parts and close to settlements, often with abandoned terraces, to deciduous forests and some extensions of coniferous forests, to pastures at higher altitudes.

\subsubsection{Nus and Saint-Marcel subarea}

This subarea has a surface of around $82 \mathrm{~km}^{2}$ and reaches from 500 to $3500 \mathrm{~m}$ a.s.l. It includes the Saint-Barthelemy watershed, characterised by steep and high slopes and a considerably developed hydrological network (around $273 \mathrm{~km}$, tributaries of the Saint-Barthelemy river) with steep slopes and consequently high solid transport. A considerable part of the slopes is used as pastures. At higher elevations, $\mathrm{Pi}$ nus cembra prevails, sometimes mixed with Larix decidua, and with Rhodoreto-vaccinietum associations. Very sunny slopes, where dryness is a limiting factor for Picea abies and Pinus cembra, are often colonised by pure Larix decidua forest. The Saint Marcel area shares the lower border, corresponding to the Dora Baltea river, with the Nus area, and covers a $28 \mathrm{~km}^{2}$ area (from 500 to $1350 \mathrm{~m}$ a.s.1.), which showed a high density of shallow mass movements during the year 2000 flood. The area is characterised by strong anthropogenic pressure and high infrastructure and settlement density. The topography is characterised by a flat area (Dora alluvial deposits), followed by mixed moraine and debris deposits. The vegetation in the flat area is quite fragmented, consisting of meadows, leisure areas and orchards. In the sloping parts, the main vegetation covers are abandoned chestnut forests, pioneer species, mixed forests with broadleaved and conifer species.

\subsection{Soil sampling, soil analyses, and statistics}

In the whole study area, characterised by a particularly high density of shallow soil movements and diffuse erosion after the year 2000 event, the soils were relatively young and the majority of them can be classified, according to soil classification systems, as Entisols and Inceptisols (after Soil Survey Staff, 2006, see Supplement), or Regosols and Cambisols (after IUSS Working Group, 2006). The sampling strategy was based on the soil associations and corresponding land units in the study areas. The Supplement contains a detailed description of land units and, for each of them, a representative soil profile. A total of 41 soil profiles, characterised and classified for the preparation of a 1:10000 soil map, were sampled at two depths: $0-20 \mathrm{~cm}$ (A horizons, topsoil, T), and about $20-70 \mathrm{~cm}$ (i.e. $\mathrm{AC}$ and $\mathrm{C}$ and a minority of Bw horizons, subsoil, S), considering the average depth of soil instability phenomena involving $20-80 \mathrm{~cm}$ of soil. Soil profiles were described in the field and sampled by horizons for the soil map preparation, then the samples were oven dried, sieved, analysed, and finally soils were classified. For this 
Table 2. Considered physical properties for topsoil (T) and subsoil (S) samples. Standard dev. in brackets $(n=41)$, significance levels expressed by p-values (Na-hex indicates soil texture without, $\mathrm{H}_{2} \mathrm{O}_{2}$ with soil organic matter removal).

\begin{tabular}{lrrr}
\hline Soil properties & $\mathrm{T}$ & $\mathrm{S}$ & $p$ \\
\hline Coarse sand $(\%)_{\mathrm{Na}-\text { hex }}$ & $36.6(11.0)$ & $36.8(10.0)$ & 0.940 \\
Fine sand $(\%)_{\mathrm{Na}-\text { hex }}$ & $38.4(10.8)$ & $32.6(6.5)$ & 0.006 \\
Coarse silt $(\%)_{\mathrm{Na}-\text { hex }}$ & $9.6(2.6)$ & $11.2(2.5)$ & 0.010 \\
Fine silt $(\%)_{\mathrm{Na}-\text { hex }}$ & $11.6(4.9)$ & $14.3(6.3)$ & 0.038 \\
Clay $(\%) \mathrm{Na}-$ hex & $3.8(2.0)$ & $5.2(3.7)$ & 0.024 \\
Coarse sand $(\%)_{\mathrm{H}_{2} \mathrm{O}_{2}}$ & $29.4(10.3)$ & $34.6(12.2)$ & 0.044 \\
Fine sand $(\%)_{\mathrm{H}_{2} \mathrm{O}_{2}}$ & $32.6(7.3)$ & $30.2(7.1)$ & 0.145 \\
Coarse silt $(\%)_{\mathrm{H}_{2} \mathrm{O}_{2}}$ & $10.6(4.2)$ & $10.6(3.4)$ & 0.969 \\
Fine silt $(\%) \mathrm{H}_{2} \mathrm{O}_{2}$ & $16.9(3.6)$ & $14.3(6.3)$ & 0.397 \\
Clay $(\%) \mathrm{H}_{2} \mathrm{O}_{2}$ & $10.4(3.6)$ & $5.2(3.4)$ & 0.018 \\
\hline Total aggregate loss $(\%)$ & $49(24)$ & $67(21)$ & 0.000 \\
\hline$D_{\mathrm{H}_{2} \mathrm{O}_{2}}-D_{\mathrm{f}_{\mathrm{Na}}}$ & $0.169(0.0897)$ & $0.112(0.0882)$ & 0.008 \\
Coarse sand $\mathrm{H}_{2} \mathrm{O}_{2} / \mathrm{Coarse}$ sand ${ }_{\mathrm{Na}-\text { hex }}$ & $0.83(0.18)$ & $0.91(0.21)$ & 0.069 \\
Clay $\mathrm{H}_{2} \mathrm{O}_{2} / \mathrm{Clay}_{\mathrm{Na}-\text { hex }}$ & $3.58(2.72)$ & $2.53(2.18)$ & 0.069 \\
LL $(\%)$ & $49(12)$ & $37(10)$ & 0.000 \\
PL $(\%)$ & $38(11)$ & $27(9)$ & 0.000 \\
PI $(\%)$ & $10(3)$ & $9(4)$ & 0.869 \\
\hline
\end{tabular}

research, we focused on the $\mathrm{T}$ and $\mathrm{S}$ depths.

Soil $\mathrm{pH}$ was determined potentiometrically (SISS, 2000), total organic $\mathrm{C}$ (TOC) and total $\mathrm{N}$ content (TN) were determined by dry combustion with an elemental analyser. Cation exchange capacity (CEC) was analysed with the $\mathrm{BaCl}_{2}$ triethanolamine method at $\mathrm{pH} 8.1$ (Rhoades, 1982); the carbonate content determination followed the SISS (2000) official method. Soil texture was determined by the pipette method with Na-hexametaphosphate without and with soil organic matter (SOM) oxidation with $\mathrm{H}_{2} \mathrm{O}_{2}$ (Gee and Bauder, 1986). The skeleton content was estimated in the field by volume. The Atterberg liquid limit (LL) was determined with a semi automatic cone penetrometer (SISS, 2000), and the plastic limit (PL) with the thread rolling method (SISS, 2000). Soil aggregate stability was determined by wet sieving (Zanini et al., 1998), measuring aggregate loss $(\%)$ for different sieving times $(5,10,15,20$, 40, $60 \mathrm{~min}$.), aggregate loss for abrasion, aggregate loss for slaking, total aggregates loss, and aggregates half-life (min).

All analyses and physical determinations were performed in duplicate, and then averaged.

In order to summarize soil texture with a synthetic index, we estimated the fragmentation fractal dimension $\left(D_{\mathrm{f}}\right)$ from size-distributions with and without SOM removal, as done in a previous work (Stanchi et al., 2008a) where $D_{\mathrm{f}}$, ranging from 2 to 3, was calculated by linear regression of the cumulative mass for soil size fractions $(<2 \mathrm{~mm}) \mathrm{vs}$. the fraction upper size radius (Tyler and Wheatcraft, 1992). In general, $D_{\mathrm{f}}$ close to 2 indicates a coarser aggregation type, i.e. a relative abundance of coarse aggregates (Anderson et al., 1998).

We performed factor analysis using covariance and correlation data matrix, considering the following variables that are known to influence soil quality and conservation and are likely to have a direct or indirect relationship with the studied phenomena (Seybold et al., 1999): pH, total aggregates loss and aggregates half-life after wet sieving (soil stability), liquid limit (LL), plastic limit (PL), plastic index (PI $=\mathrm{LL}-$ PL), soil texture (3 classes) with/without soil organic matter (SOM) removal and corresponding $D_{\mathrm{f}}$ values (Stanchi et al., 2008a), clay and coarse sand aggregation index (Stanchi et al., 2008a), cation exchange capacity (CEC), exchangeable cations, base saturation, carbonates, and total $\mathrm{C}$ and $\mathrm{N}$ contents. All analyses were performed in double. Among the above mentioned properties, aggregate stability and the Atterberg limits are related to soil structure and erodibility. The texture without SOM removal and the corresponding Df are useful indexes of soil aggregation and reflect changes in soil physical quality. Organic matter content promotes soil aggregation and structure creation, as well as inorganic cements (carbonates). The CEC, being related to clay content, is also known to be related to the Atterberg limits (higher CEC is typical of soils with better consistency properties).

Factor analysis was performed considering topsoils and subsoils separately, using covariance and correlation data, with varimax rotation, in order to maximise the correlation between factors and measured properties. Prior to factor analysis, we verified the normal distribution of variables through a Kolmogorov-Smirnov test.

All the statistical treatment of data was performed with SPSS (version 17.0). 


\section{Results and discussion}

The soils in the study areas were generally characterised by limited development, as we can expect for Alpine environments. Refering to WRB (IUSS Working Group, 2006), most of them were classified as Regosols, a few as Cambisols, the latter in recently abandoned almost flat, non-terraced, agricultural areas. The average total depth of A horizons varied with site conditions and management in the range 5$50 \mathrm{~cm}(p<0.01$, data not shown). Pastures and abandoned terraced areas showed deeper A horizons (both $29 \mathrm{~cm}$ average depth, st. dev 13 and 22, respectively), as did coniferous forests $(30 \mathrm{~cm}$ average depth, st. dev. 16), while broadleaved and mixed coniferous-broadleaved woods showed less developed A horizons ( $14 \mathrm{~cm}$ average depth, st. dev. 8 , and $16 \mathrm{~cm}$ average depth, st. dev. 8, respectively). A horizon development was also significantly related to slope classes, as slopes $>30^{\circ}$ showed significantly lower depths (less than $20 \mathrm{~cm}$, $p<0.01$ ).

Both topsoils and subsoils showed coarse textures in Nahexametaphosphate (Table 2) with high sand content (more than $50 \%$ by weight) and maximum $5 \%$ of clay content, for both determination methods. Topsoils (T) and subsoils (S) showed significant differences in many relevant physical properties (Table 2). In general, soil texture was finer in the subsoils, i.e. richer in silt and clay fractions, due to limited aggregation processes in $\mathrm{S}$ samples (when organic matter is not removed, and therefore aggregates are still present together with primary particles). Moreover no significant differences were observed after organic cements removal, as soil organic matter played, as expected, a relevant role in aggregation mainly in topsoils. Topsoil samples were therefore characterised by more pronounced aggregation, as also indicated by the higher $D_{\mathrm{f}_{\mathrm{H}_{2} \mathrm{O}_{2}}}-D_{\mathrm{f}_{\mathrm{Na}}}$ index (Stanchi et al., 2008a), and by the coarse sand and clay ratio, higher LL and PL, i.e. better resistance to liquefaction, despite the overall low plasticity (low PI independent of soil depths).

Aggregate losses (Fig. 2) were always higher (all sieving times, $p<0.001$ ) for subsoils both in quantitative terms, and in loss velocity (data not shown), indicating greater vulnerability. Topsoil were quite vulnerable but aggregates showed a considerably lower destruction rate (about double time required for the breakdown of $50 \%$ aggregates, data not shown), which can be seen as a measure of soil physical quality. In the study by Freppaz et al. (2002) comparable topsoil aggregate loss were reported for ski slopes with high intensity of management, while undisturbed forest and recent clear-cut areas showed much lower soil loss (around 20\%). Topsoils also showed better consistency properties (higher LL and PL, $p<0.001$ ), indicating a higher resistance to plasticity loss and liquefaction processes. However, both depths showed a limited plasticity interval, i.e. plasticity index (PI), as we may expect in Alpine environments.

Also chemical properties (Table 3) confirmed the differences between soil depths ( $\mathrm{T}$, topsoil; $\mathrm{S}$, subsoil), mainly in
SOIL LOSSES (\%)

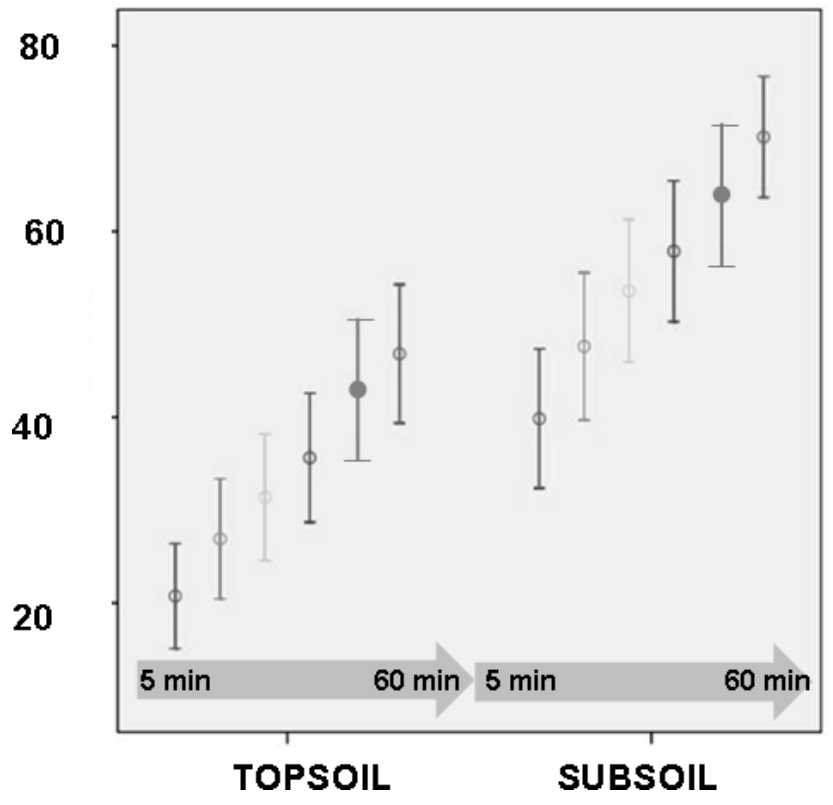

Fig. 2. Soil losses (\%) for topsoil and subsoil samples ( $n=41$ each). The lines represent average values \pm 2 standard error. Wet sieving was performed for 6 sieving times $(5,10,15,20,40,60 \mathrm{~min}$.).

Table 3. Considered chemical properties for topsoil (T) and subsoil (S) samples. Standard dev. in brackets $(n=41)$, significance levels expressed by p-values (CEC: cation exchange capacity; * significant differences between values in the same lines, $p<0.05$ ).

\begin{tabular}{lrrr}
\hline Soil properties & $\mathrm{T}$ & $\mathrm{S}$ & $p$ \\
\hline $\mathrm{pH}$ & $6.7(1.2)$ & $7.1(1.1)$ & 0.115 \\
$\mathrm{CEC}\left(\mathrm{cmolc} \mathrm{kg}^{-1}\right)$ & $14.7(7.3)$ & $8.3(4.6)$ & $0.000^{*}$ \\
Exch Ca $\left(\mathrm{cmolc} \mathrm{kg}^{-1}\right)$ & $14.8(12.3)$ & $8.8(7.6)$ & $0.014^{*}$ \\
Exch $\mathrm{Mg}\left(\mathrm{cmolc} \mathrm{kg}^{-1}\right)$ & $1.8(1.4)$ & $1.1(1.1)$ & $0.020^{*}$ \\
Exch K $\left(\mathrm{cmolc} \mathrm{kg}^{-1}\right)$ & $0.31(0.21)$ & $0.14(0.08)$ & $0.000^{*}$ \\
Organic C $\left(\mathrm{g} \mathrm{kg}^{-1}\right)$ & $37.0(27.0)$ & $13.9(11.2)$ & $0.000^{*}$ \\
$\mathrm{~N}\left(\mathrm{~g} \mathrm{~kg}^{-1}\right)$ & $2.65(2.33)$ & $4.3(1.4)$ & 0.426 \\
$\mathrm{C} / \mathrm{N}$ & $16.4(5.7)$ & $15.5(9.5)$ & 0.562 \\
\hline
\end{tabular}

the cation exchange complex and the organic $\mathrm{C}$ content, both showing a sharp decrease with soil depth. The carbonate content (data not shown), as well as $\mathrm{pH}$ (Table 3), showed considerable heterogeneity in the study areas, depending on the parent material. For such properties, no uniform trend was observable along the soil profiles.

Correlation matrices for $\mathrm{T}$ and $\mathrm{S}$ samples are presented in Tables 4 and 5, respectively. In the topsoils and subsoils, LL and PL showed significant positive linear correlation with the organic carbon content, indicating that the organic matter content, despite its modest amounts, plays a major role in the Alpine environment concerning the conservation of 
Table 4. Correlation matrix between soil properties, topsoils (* significant for $p<0.05 ; * * p<0.01$ ).

\begin{tabular}{|c|c|c|c|c|c|c|c|c|c|c|c|c|c|c|c|}
\hline & $\mathrm{pH}$ & $\mathrm{C}$ & $\mathrm{N}$ & CEC & Total loss & LL & PL & $D_{\mathrm{f}_{\mathrm{H}_{2} \mathrm{O}_{2}}}$ & $D_{\mathrm{f}_{\mathrm{Na}}}$ & $\operatorname{Sand}_{\mathrm{Na}}$ & Silt $_{\mathrm{Na}}$ & Clay $_{\mathrm{Na}}$ & Sand $_{\mathrm{H}_{2} \mathrm{O}_{2}}$ & Silt $_{\mathrm{H}_{2} \mathrm{O}_{2}}$ & Clay $_{\mathrm{H}_{2} \mathrm{O}_{2}}$ \\
\hline $\mathrm{pH}$ & & $-0.437 *$ & -0.224 & $-0.399 * *$ & $0.593^{* *}$ & $-0.361 *$ & $-0.463 *$ & $-0.633^{* *}$ & 0.0091 & -0.115 & -0.046 & 0.042 & $0.374 * *$ & -0.046 & $-0.607 * *$ \\
\hline $\mathrm{C}$ & & & $0.753^{* *}$ & $-0.555^{* *}$ & $-0.509^{* *}$ & $0.804^{* *} *$ & $0.658^{* *}$ & $0.435^{* *}$ & -0.237 & 0.246 & -0.244 & -0.202 & -0.169 & -0.073 & $0.473^{* *}$ \\
\hline $\mathrm{N}$ & & & & -0.123 & $-0.375^{* *}$ & -0.032 & -0.043 & -0.201 & 0.015 & 0.268 & -0.235 & $-0.321 *$ & -0.121 & -0.107 & $0.434 * *$ \\
\hline CEC & & & & & $-0.424^{* *}$ & $0.563^{* *}$ & $0.573^{* *}$ & $0.397 * *$ & $-0.344 * *$ & 0.200 & -0.167 & $-0.284 * *$ & -0.209 & -0.036 & $0.438 * *$ \\
\hline Total loss & & & & & & $-0.617^{* *}$ & $-0.594^{* *}$ & $-0.634^{* *}$ & -0.094 & -0.185 & 0.222 & 0.031 & 0.115 & 0.232 & $-0.650 * *$ \\
\hline LL & & & & & & & $0.977^{* * *}$ & $0.383^{*}$ & -0.121 & $0.419 * *$ & -0.448 & -0.233 & -0.033 & -0.170 & $0.410^{* *}$ \\
\hline PL & & & & & & & & $0.341^{* *}$ & -0.260 & $0.408 *$ & $-0.411 * *$ & $-0.313^{*}$ & 0.038 & -0.233 & $0.378^{* *}$ \\
\hline$D_{\mathrm{f}_{\mathrm{H}_{2} \mathrm{O}_{2}}}$ & & & & & & & & & 0.122 & $-0.78 * *$ & $0.679 * *$ & 0.939 & $-0.278^{* *}$ & $0.356^{*}$ & 0.016 \\
\hline$D_{\mathrm{f}_{\mathrm{Na}}}$ & & & & & & & & & & 0.132 & $-0.171^{*}$ & 0.014 & -0.174 & 0.024 & $0.329 *$ \\
\hline Sanda $_{\mathrm{Na}}$ & & & & & & & & & & & $-0.985 * *$ & $-0.847 * *$ & 0.286 & $-0.449 *$ & 0.102 \\
\hline Silt $_{\mathrm{Na}}$ & & & & & & & & & & & & $0.742 * *$ & -0.261 & $0 . .433 *$ & -0.124 \\
\hline Clay $_{\mathrm{Na}}$ & & & & & & & & & & & & & -0.305 & $0.408^{* *}$ & -0.11 \\
\hline Sand $_{\mathrm{H}_{2} \mathrm{O}_{2}}$ & & & & & & & & & & & & & & $-0.31^{* *}$ & $-0.470^{*}$ \\
\hline Silt $\mathrm{H}_{2} \mathrm{O}_{2}$ & & & & & & & & & & & & & & & -0.028 \\
\hline
\end{tabular}

Table 5. Correlation matrix between soil properties, subsoils (* significant for $p<0.05$; ** $p<0.01$ ).

\begin{tabular}{|c|c|c|c|c|c|c|c|c|c|c|c|c|c|c|c|}
\hline & $\mathrm{pH}$ & $\mathrm{C}$ & $\mathrm{N}$ & CEC & Total loss & LL & PL & $D_{\mathrm{f}_{\mathrm{H}_{2} \mathrm{O}_{2}}}$ & $D_{\mathrm{f}_{\mathrm{Na}}}$ & Sand $_{\mathrm{Na}}$ & Silt $_{\mathrm{Na}}$ & Clay $_{\mathrm{Na}}$ & Sand $_{\mathrm{H}_{2} \mathrm{O}_{2}}$ & Silt $\mathrm{H}_{2} \mathrm{O}_{2}$ & Clay $_{\mathrm{H}_{2} \mathrm{O}_{2}}$ \\
\hline $\mathrm{pH}$ & -0.093 & $0.315^{*}$ & $-0.45^{* *}$ & 0.252 & -0.159 & -0.093 & -0.029 & 0.194 & 0.051 & -0.02 & -0.109 & -0.058 & 0.044 & 0.073 & \\
\hline $\mathrm{C}$ & & & 0.083 & $-0.582^{* *}$ & $-0.47 * *$ & $0.820^{* *}$ & $0.860^{* *}$ & 0.065 & $-0.502^{* * *}$ & $0.347^{*}$ & $-0.292^{*}$ & $-0.348^{*}$ & -0.017 & -0.034 & 0.116 \\
\hline $\mathrm{N}$ & & & & -0.278 & 0.025 & -0.032 & -0.043 & -0.201 & -0.241 & 0.268 & -0.235 & -0.245 & 0.149 & -0.117 & -0.161 \\
\hline CEC & & & & & $-0.659^{* *}$ & $0.464 * *$ & $0.333^{*}$ & -0.026 & -0.284 & 0.243 & -0.226 & -0.202 & 0.015 & -0.086 & 0.155 \\
\hline Total loss & & & & & & $-0.580^{* *}$ & $-0.380^{*}$ & 0.005 & 0.217 & -0.191 & 0.165 & 0.189 & -0.207 & $0.294^{*}$ & -0.070 \\
\hline LL & & & & & & & $0.936^{* *}$ & -0.059 & $-0.470^{* *}$ & $0.404^{*}$ & $-0.355^{*}$ & $-0.377^{*}$ & 0.180 & -0.228 & -0.007 \\
\hline PL & & & & & & & & -0.017 & $-0.496^{* *}$ & $0.359 *$ & -0.297 & $-0.383^{*}$ & 0.136 & -0.163 & -0.027 \\
\hline$D_{\mathrm{f}_{\mathrm{H}_{2} \mathrm{O}_{2}}}$ & & & & & & & & & $0.554^{* * *}$ & $-0.620^{* *}$ & $0.578 * *$ & $0.600^{* *}$ & $-0.699^{* *}$ & $0.435^{* *}$ & $0.958^{* *}$ \\
\hline$D_{\mathrm{f}_{\mathrm{Na}}}$ & & & & & & & & & & $-0.797^{* *}$ & $0.627^{* * *}$ & $0.916^{* *}$ & $-0.505^{* *}$ & $0.409^{* *}$ & $0.516^{* *}$ \\
\hline Sanda ${ }_{\mathrm{Na}}$ & & & & & & & & & & & $-0.963^{* *}$ & $* 0.759 * *$ & $0.651^{* *} *$ & $-0.606^{* *}$ & $-0.537^{* * *}$ \\
\hline Silt $_{\mathrm{Na}}$ & & & & & & & & & & & & $0.556^{* *}$ & $0.556^{* *}$ & $-0.637 * *$ & $0.487^{* *} *$ \\
\hline Clay $_{\mathrm{Na}}$ & & & & & & & & & & & & & 0.009 & $0.330 *$ & $0.482 * *$ \\
\hline Sand $_{\mathrm{H}_{2} \mathrm{O}_{2}}$ & & & & & & & & & & & & & & $-0.961^{* *}$ & $-0.755^{* *}$ \\
\hline Silt $_{\mathrm{H}_{2} \mathrm{O}_{2}}$ & & & & & & & & & & & & & & & $0.544 * *$ \\
\hline
\end{tabular}

soil consistency. The positive correlation with CEC was also highly significant at both depths, confirming that soil consistency is positively influenced by the cation exchange complex, as often stated in literature (Seybold et al., 2008). For T samples, soil consistency (i.e. high LL and PL, Table 4) showed a strong negative relationship with total soil loss, indicating that soil loss by water erosion is somehow mitigated when soils have good consistency properties. The same trend was observed for S samples (Table 5), but the correlation coefficients were lower, though the relation was still significant.

The Atterberg limits showed a strong correlation in both $\mathrm{T}$ and $\mathrm{S}$ subgroups, confirming the linear relationship evidenced in literature (De Jong et al., 1990; Stanchi et al., 2009). The liquid limit of topsoils showed a positive correlation with the sand-sized fraction (Sand in Nahexametaphosphate) and with the clay content after SOM removal, indicating that the liquid limit is related to the aggregation properties and to the clay fraction abundance. Similar correlation coefficients could be established for the plastic limit in T samples. For subsoil samples, the correlation of the liquid limit with coarse-sand sized fraction was still present, although less significant.

The liquid limit of topsoil was positively correlated with fractal dimension after SOM removal: higher consistency
Table 6. Eigenvalue, variance and cumulative variance explained by factor analysis in topsoil samples $(n=41)$.

\begin{tabular}{lrrr}
\hline Factors & Eigenvalues & Variance & $\begin{array}{r}\text { Cumulative } \\
\text { variance }\end{array}$ \\
\hline 1 & 8.24 & 0.23 & 0.23 \\
2 & 5.19 & 0.23 & 0.46 \\
3 & 2.67 & 0.16 & 0.62 \\
4 & 1.96 & 0.11 & 0.74 \\
5 & 1.17 & 0.06 & 0.80 \\
\hline
\end{tabular}

corresponded to samples with higher $D$, i.e. with higher content of fine primary particle fractions (clay, fine silt). For subsoil, a negative significant relation was observed only between LL and $D_{\mathrm{f}_{\mathrm{Na}}}$, i.e. soils with higher $D$ (higher relative abundance of fine aggregated fractions) showed a lower LL, although a positive relation was generally expected, as LL is generally related to the fine fractions (clay in particular). In this case the different behavior might depend on the determination method (no SOM removal). In fact, a similar relation is visible between clay and silt contents (without SOM removal) and LL. 
Table 7. Proportion of variance (varimax rotation) for soil properties of the retained factors in topsoil samples $(n=41)$.

\begin{tabular}{lrrrrr}
\hline Soil properties & Factor 1 & Factor 2 & Factor 3 & Factor 4 & Factor 5 \\
\hline $50 \%$ aggregates disruption time & 0.16 & 0.18 & 0.27 & -0.14 & 0.38 \\
$\mathrm{LL}$ & 0.92 & 0.17 & 0.034 & -0.066 & 0.12 \\
$\mathrm{PL}$ & 0.91 & 0.21 & 0.012 & -0.12 & 0.072 \\
Sand $\mathrm{Na}$ & 0.14 & 0.95 & -0.19 & -0.24 & 0.49 \\
$\mathrm{Silt} \mathrm{Na}$ & -0.145 & -0.937 & 0.155 & 0.012 & -0.037 \\
$\mathrm{Clay} \mathrm{Na}_{\mathrm{Sand}} \mathrm{H}_{2} \mathrm{O}_{2}$ & -0.11 & -0.90 & 0.27 & 0.058 & -0.078 \\
$\mathrm{Silt}_{\mathrm{H}_{2} \mathrm{O}_{2}}$ & 0.034 & 0.23 & -0.93 & -0.099 & 0.016 \\
$\mathrm{Clay}_{\mathrm{H}_{2} \mathrm{O}_{2}}$ & -0.34 & -0.18 & 0.76 & 0.21 & -0.15 \\
$\mathrm{CS}_{\mathrm{H}_{2}} \mathrm{O}_{2} / \mathrm{CS}_{\mathrm{Na}}$ & 0.45 & -0.20 & 0.77 & -0.12 & 0.20 \\
$\mathrm{Clay}_{\mathrm{H}_{2} \mathrm{O}_{2}} / \mathrm{Clay} \mathrm{Na}$ & -0.30 & -0.14 & -0.50 & -0.14 & 0.33 \\
$D_{\mathrm{N}_{\mathrm{Na}}}$ & 0.46 & 0.73 & 0.31 & -0.10 & 0.22 \\
$D_{\mathrm{f}_{2}} \mathrm{O}_{2}$ & -0.14 & -0.94 & 0.20 & -0.19 & -0.12 \\
$\mathrm{CEC}$ & 0.44 & -0.18 & 0.80 & -0.16 & 0.17 \\
$\mathrm{Mg}$ & 0.73 & 0.15 & 0.099 & 0.29 & 0.10 \\
$\mathrm{Ca}$ & 0.006 & -0.33 & 0.30 & 0.57 & -0.44 \\
$\mathrm{~K}$ & 0.30 & 0.008 & 0.08 & 0.80 & 0.065 \\
$\mathrm{BS}$ & 0.004 & 0.40 & -0.17 & 0.36 & 0.38 \\
$\mathrm{pH}$ & -0.17 & -0.15 & 0.009 & 0.89 & 0.037 \\
$\mathrm{~N}$ & -0.45 & -0.17 & -0.48 & 0.55 & 0.24 \\
$\mathrm{C}$ & 0.71 & 0.39 & 0.086 & 0.22 & 0.21 \\
$\mathrm{C} / \mathrm{N}$ & 0.84 & 0.34 & 0.036 & 0.10 & 0.006 \\
$D_{\mathrm{N}_{\mathrm{Na}}} / D_{\mathrm{f}_{\mathrm{H}} \mathrm{O}_{2}}$ & -0.31 & -0.21 & 0.059 & -0.26 & -0.77 \\
\hline Total aggregate loss & 0.41 & 0.80 & 0.29 & -0.081 & 0.22 \\
\hline & -0.84 & 0.057 & -0.25 & 0.30 & -0.047 \\
\hline
\end{tabular}

Table 8. Eigenvalue, variance an cumulative variance explained by factor analysis in subsoil samples $(n=41)$.

\begin{tabular}{lrrr}
\hline Factors & Eigenvalues & Variance & $\begin{array}{r}\text { Cumulative } \\
\text { variance }\end{array}$ \\
\hline 1 & 7.4 & 0.25 & 0.25 \\
2 & 4.6 & 0.15 & 0.40 \\
3 & 3.5 & 0.15 & 0.55 \\
4 & 2.2 & 0.12 & 0.67 \\
5 & 1.9 & 0.11 & 0.78 \\
6 & 1.3 & 0.10 & 0.88 \\
\hline
\end{tabular}

Factor analysis was carried out using the following variables: LL; PL; texture for the two determination methods; $\mathrm{C}$ and $\mathrm{N}$ contents, $\mathrm{C} / \mathrm{N}$ ratio; CEC, exchangeable cations; clay and coarse sand ratio; and soil losses, $D_{\mathrm{f}_{2} \mathrm{O}_{2}}, D_{\mathrm{f}_{\mathrm{Na}}}$, $D_{\mathrm{f}_{\mathrm{H}_{2} \mathrm{O}_{2}}}-D_{\mathrm{f}_{\mathrm{Na}}}$. In the case of correlation matrix, we retained the factors with eigenvalues $>1$, and varimax rotation was adopted to maximize correlations between factors and measured properties for both $\mathrm{T}$ and $\mathrm{S}$ samples. Extracted communalities were always high (data not shown), always exceeding 0.700 , indicating that the extracted components were representative of the variable group, i.e. they have a significant contribution to the factor (Ayoubi and Khormali, 2008).
For topsoil samples (Table 6) five factors explained $80 \%$ of the total variance. The first two factors were able to explain most of the variance. For subsoil samples (Table 7) 6 models were retained, accounting for a cumulative variance of $88 \%$. Factor 1 was the most relevant in terms of explained variance ( $25 \%$ of the total variance), factors 2,3 , and 4 contributed for around $15 \%$ each, while a more limited contribution was given by factors 5 and 6 .

In topsoils, Factor 1 (Table 8), explaining about $25 \%$ variance, was characterised by a high positive loading of LL (0.92) and PL (0.91), of CEC (0.73) and organic $\mathrm{C}(0.843)$, and a negative loading of total aggregate loss $(-0.84)$. Depending on the distribution of weights (loadings) we tried to relate each factor with a relevant soil property/soil function (Shukla et al., 2006; Ayoubi and Khormali, 2008). Factor 1 was therefore related to soil structure and strength, as good soil structure and consistency are important for preventing topsoil losses. Factor 2 showed negative loads with clay $(-0.90)$ and silt $(-0.94)$ contents without SOM removal, as well as with $D_{\mathrm{f}_{\mathrm{Na}}}(-0.94)$, while it showed positive loads with sand content without SOM removal (0.95), clay aggregation ratio (0.73), and between the difference between $D_{\mathrm{f}}$ values $(0.80)$, which is known as a measure of soil aggregation (Stanchi et al., 2008a). Therefore, we identified factor 2 as aggregation factor. Factor 3 was related to texture and parent material, as it was influenced by soil texture after 
Table 9. Proportion of variance (varimax rotation) for soil properties of the retained factors, in subsoil samples $(n=41)$.

\begin{tabular}{lrrrrrr}
\hline Soil properties & Factor 1 & Factor 2 & Factor 3 & Factor 4 & Factor 5 & Factor 6 \\
\hline $50 \%$ aggregates disruption time & -0.23 & 0.73 & 0.057 & -0.34 & -0.20 & -0.32 \\
$\mathrm{LL}$ & -0.14 & 0.91 & 0.061 & 0.11 & -0.042 & -0.17 \\
$\mathrm{PL}$ & -0.093 & 0.92 & -0.111 & 0.061 & 0.058 & 0.009 \\
$\mathrm{Sand}$ & -0.88 & 0.11 & 0.32 & 0.17 & 0.026 & -0.037 \\
$\mathrm{Silt} \mathrm{Na}$ & 0.86 & -0.10 & -0.17 & -0.22 & 0.005 & 0.070 \\
$\mathrm{Clay}$ & 0.69 & -0.10 & -0.64 & 0.028 & -0.11 & -0.06 \\
$\mathrm{Sand}$ & -0.88 & 0.23 & -0.005 & 0.13 & -0.33 & 0.075 \\
$\mathrm{Hil}_{2} \mathrm{O}_{2}$ & 0.69 & -0.34 & -0.15 & -0.34 & 0.48 & -0.054 \\
$\mathrm{Clay}_{\mathrm{H}_{2}} \mathrm{O}_{2}$ & 0.92 & 0.037 & 0.038 & 0.28 & -0.069 & -0.081 \\
$\mathrm{CS}_{\mathrm{H}_{2}} \mathrm{O}_{2} / \mathrm{CS}_{\mathrm{Na}}$ & 0.16 & 0.26 & -0.003 & 0.049 & -0.88 & -0.023 \\
$\mathrm{Clay}_{\mathrm{H}_{2} \mathrm{O}_{2}} / \mathrm{Clay} \mathrm{Na}$ & -0.168 & 0.058 & 0.93 & 0.18 & -0.09 & 0.11 \\
$D_{\mathrm{f}_{\mathrm{Na}}}$ & 0.76 & -0.049 & -0.63 & 0.039 & -0.005 & -0.031 \\
$D_{\mathrm{f}_{\mathrm{H}_{2}} \mathrm{O}_{2}}$ & 0.91 & -0.002 & -0.05 & 0.29 & -0.06 & -0.005 \\
$\mathrm{CEC}$ & -0.025 & 0.33 & 0.055 & 0.055 & 0.13 & -0.88 \\
$\mathrm{Mg}$ & 0.32 & 0.012 & 0.15 & 0.30 & 0.77 & 0.16 \\
$\mathrm{Ca}$ & 0.11 & 0.041 & 0.35 & 0.86 & 0.016 & 0.062 \\
$\mathrm{~K}$ & -0.161 & -0.013 & -0.10 & 0.83 & -0.15 & -0.23 \\
$\mathrm{BS}$ & 0.16 & -0.18 & 0.26 & 0.64 & 0.054 & 0.57 \\
pH & -0.44 & -0.19 & 0.33 & 0.60 & 0.21 & 0.55 \\
$\mathrm{~N}$ & -0.24 & 0.080 & 0.42 & -0.13 & -0.26 & 0.60 \\
$\mathrm{C}$ & -0.060 & 0.85 & 0.19 & -0.32 & -0.22 & 0.007 \\
$\mathrm{C} / \mathrm{N}$ & -0.011 & -0.021 & -0.32 & -0.21 & 0.76 & -0.18 \\
$D_{\mathrm{f}_{\mathrm{Na}}} / D_{\mathrm{f}_{\mathrm{H}_{2}} \mathrm{O}_{2}}$ & -0.21 & 0.073 & 0.92 & 0.25 & -0.055 & 0.043 \\
\hline Total aggregate loss & -0.20 & -0.59 & -0.42 & 0.13 & 0.18 & 0.50 \\
\hline
\end{tabular}

the removal of organic binding agents, that means by the primary particles content, independent of aggregation, and by the corresponding fractal dimension, which is a global masssize distribution index. Factor 4 was mainly dependent on soil chemical properties related to the cation exchange complex (in particular exchangeable $\mathrm{Ca}$ ) and with $\mathrm{pH}$ and base saturation. It could be therefore related to soil bases and reaction. The last factor, number 5 , was apparently related to the organic matter mineralization, and it showed a negative load of the $\mathrm{C} / \mathrm{N}$ ratio $(-0.77)$.

In subsoils, Factor 1 (Table 9) was influenced by soil texture and aggregation, as it showed high positive loadings with $D_{\mathrm{f}} \mathrm{s}$ (which are known to be positively related to clay content, Tyler and Wheatcraft, 1992; Stanchi et al., 2008a), and with clay and silt fractions (both methods). Moreover, it showed a negative loading with sand content without SOM removal, i.e. with aggregates in the sand size range. Factor 2 was clearly related to Atterberg limits, i.e. soil consistency, and also with $\mathrm{C}$ content, which is known to improve soil plasticity and resistance to liquefaction. It showed also a positive loading from the aggregate loss velocity. Therefore, factor 2 might be identified as a aggregate vulnerability/soil consistency factor. Factor 3 was strongly related to clay $D_{\mathrm{f}_{\mathrm{Na}}}$ and the corresponding clay content, i.e. with fine aggregate classes (i.e. aggregated clay). Factor 4 showed a relation with the exchangeable cation complex, as it had high positive loadings with exchangeable $\mathrm{K}, \mathrm{Mg}$, base saturation, and $\mathrm{pH}$. The last two factors only explained a limited variance proportion and they were more complex to interpret. Factor 5 was related to coarse sand aggregation, and $\mathrm{Mg}$ content, while factor 6 only to CEC.

\section{Conclusions}

The soils of the study area showed a considerable vulnerability as evidenced by the shallow instability phenomena registered in the past, strictly related to severe storms and potentially with spring snow melt. In fact, topsoil horizons were often affected by water erosion and other shallow soil movements or gravitationally moved soil material such as soil slips, sometimes triggered by intense rainfall events. Topsoils $(0-20 \mathrm{~cm})$ and subsoils $(20-70 \mathrm{~cm})$ showed considerable differences in physical and chemical soil properties. Topsoils were generally characterised by better resistance to loss phenomena, due to better plasticity, structure, and consistency, while subsoils were characterised by weaker aggregation, and scarce consistency and plasticity. Such differences with soil depth indicated a sharp gradient in resistance to soil losses, and they may explain the frequency of shallow soil collapses in case of heavy and intense precipitations, as observed in the recent past. The better structure of topsoils 
was mainly related to the organic binding agents, and can therefore be affected by land management for external inputs of organic matter (manuring), management of terraced slopes, maintenance of the drainage network in agricultural areas, and use of erosion-mitigating measures. Factor analysis allowed us to identify some groups of properties that mainly affect soil behavior. The overall behavior of topsoil samples was dominated by structure, aggregation, and consistency; secondly by texture and chemical properties because subsoil samples properties were dominated by soil texture and consistency, with a lower importance of the SOM. Factor analysis helped reducing the high number of chemical and physical parameters that may affect soil vulnerability in the study area, grouping them into a limited number of factors related to soil texture, structure, and consistency. Such differences and discontinuities along the profile may explain the slip of soil horizons recorded after extreme rainfall. The set of physical properties (LL, PL, aggregate stability etc.) we investigated may help in future research to formulate indexes of soil physical quality with respect to surface soil losses in mountain environments. We are currently trying to relate physical properties to shallow hazard triggering mechanisms through continuous precipitation and soil moisture recording. Among the elements that require further insight and investigation, there are the role of skeleton in the soil behavior, the possible root reinforcement action, and the effect of the snow melting on soil structure and consistency, which is very relevant in mountain areas besides the effects of the liquid precipitation.

\section{Supplementary material related to this article is available online at: http://www.nat-hazards-earth-syst-sci.net/12/1845/2012/ nhess-12-1845-2012-supplement.pdf.}

Acknowledgements. This research was funded by Regione Valle d'Aosta - Assessorato opere pubbliche, difesa del suolo e edilizia residenziale pubblica - Dipartimento difesa del suolo e risorse idriche - Centro Funzionale.

Edited by: T. Glade

Reviewed by: two anonymous referees

\section{References}

Ajami, M., Khormali, F., Ayoubi, S. H., and Amoozadeh Omrani, R.: Changes in soil quality attributes by conversion of land use on a loess hillslope in Golestan province, Iran, in Proceedings of the 18th International Soil Meeting (ISM) on Soil Sustaining Life on Earth, Maintaining Soil and Technology, Soil Science Society of Turkey, 501-504, 2006.

Alewell, C., Meusburger, K., Brodbeck, M., and Banninger, D.: Methods to describe and predict soil erosion in mountain regions, Land. Urb. Plan., 88, 46-53, 2008.
Anderson, A. N., Mc Bratney, A. B., and Crawford, J. W.: Applications of Fractals to Soil Studies, Adv. Agr., 63, 1-76, 1998.

Arnaud-Fassetta, G., Cossart, E., and Fort, M.: Hydro-geomorphic hazards and impact of man-made structures during the catastrophic flood of June 2000 in the Upper Guil catchment (Queyras, Southern French Alps), Geomorphology, 66, 41-67, 2004.

Ayoubi, S. and Khormali, F.: Use of factor analysis to evaluate soil quality relation to land use change in Azadshar district, north of Iran, in: ISCO Proceedings, available at: http://tucson.ars.ag. gov/isco/isco15/AF.htm, 2008.

Bell, R. and Glade, T.: Quantitative risk analysis for landslides - Examples from Bíldudalur, NW-Iceland, Nat. Hazards Earth Syst. Sci., 4, 117-131, doi:10.5194/nhess-4-117-2004, 2004.

Brejda, J. J., Karlen, D. L., Smith, J. L., and Allan, D. L.: Identification of regional soil quality factors and indications in Northern Mississippi Loess Hills and Palouse Grassland, Soil Sci. Soc. Am. J., 64, 2125-2135, 2000.

Confortola, G., Maggioni, M., Freppaz, M., and Bocchiola, D.: Modelling soil removal from snow avalanches: A case study in the North-Western Italian Alps, Cold reg., Sci. Technol., 70, 43$52,2012$.

Crosta, G. B., Dal Negro, P., and Frattini, P.: Soil slips and debris flows on terraced slopes, Nat. Hazards Earth Syst. Sci., 3, 31-42, doi:10.5194/nhess-3-31-2003, 2003.

De Jong, E., Acton, D. F., and Stonehouse, H. B.: Estimating the Atterberg limits of Southern Saskatchewan soils from texture and Carbon contents, Can. J. Soil Sci., 70, 543-554, 1990.

Descroix, L. and Gautier, E.: Water erosion in the southern French Alps: climatic and human mechanisms, Catena, 50, 53-85, 2002.

Descroix, L. and Mathys, M.: Processes, spatio-temporal factors and measurements of current erosion in the French Southern Alps: a review, Earth Surf. Proc. Land., 28, 993-1011, 2003.

Donkin, M. J. and Fey, M. V.: Factor analysis of familiar properties of some natal soils with potential for afforestation, Geoderma, 48, 297-304, 1991.

Egli, M., Fitze, P., and Mirabella, A.: Weathering and evolution of soils formed on granitic, glacial deposits: results from chronosequences of Swiss alpine environments, Catena, 45, 19-47, 2001.

Filippa, G., Freppaz, M., Williams, M. W., and Zanini, E.: Major element chemistry in inner alpine snowpacks (Aosta valley Region, NW Italy), Cold Reg. Sci. Technol., 64, 1587-166, 2010.

Freppaz, M., Godone, G., Filippa, G., Maggioni, M., Lunardi, S., Williams, M. W., and Zanini, E.: Soil Erosion Caused by Snow Avalanches: a Case Study in the Aosta Valley (NW Italy), Arct. Antarct. Alp. Res., 42, 412-421, 2010.

Freppaz, M., Lunardi, S., Bonifacio, E., Scalenghe, R., and Zanini, E.: Ski slopes and stability of soil aggregates, in: Advances in Geoecology, edited by: Pagliai, M. and Jones, R., 35, 125-132, 2002.

Gee, G. W. and Bauder, J. W.: Particle-size analysis, in: Methods of Soil Analysis: Part I, edited by: Klute, A., ASA, Madison, WI, USA, 2nd Edn., 383-409, 1986.

Giannecchini, R.: Rainfall triggering soil slips in the southern Apuan Alps (Tuscany, Italy), Adv. Geosci., 2, 21-24, doi:10.5194/adgeo-2-21-2005, 2005.

Giannecchini, R., Naldini, G., D’Amato Avanzi, G., and Puccinelli, A: Modelling of the initiation of rainfall-induced debris flows in the Cardoso basin (Apuan Alps, Italy), Quat. Int., 171, 108-117, 2007. 
Karlen, D. L.: Soil quality as an indicator of sustainable tillage practices, Soil Till. Res., 78, 129-130, 2004.

Karlen, D. L., Mausbach, M. J., Doran, J. W., Cline, R. G., Harris, R. F., and Shuman, G. E.: Soil quality: a concept, definition and framework for evaluation, Soil Sci. Soc. Am. J., 61, 4-10, 1997.

Khormali, K., Ajami, M., Ayoubi, S., Srinivasarao, C., and Wani, S. P.: Role of deforestation and hillslope position on soil quality attributes oe loess-derived soils in Golestan province, Iran, Agr. Ecosys. Env., 134, 178-189, 2009.

IPCC: Contribution of Working Groups I, II and III to the Fourth Assessment Report of the Intergovernmental Panel on Climate Change Core Writing Team, edited by: Pachauri, R. K. and Reisinger, A., IPCC, Geneva, Switzerland, 2007.

IUSS Working Group: WRB: World reference base for soil resources, World Soil Resources Reports No. 103, 2nd Edn., FAO, Rome, 2006.

Lindner, M., Maroschek, M., Netherer, S., Kremer, A., Barbati, A., Garcia-Gonzalo, J., Seidl, R., Delzon, S., Corona, P., Kolström, M., Lexer, M. J., and Marchetti, M.: Climate change impacts, adaptive capacity, and vulnerability of European forest ecosystems, Forest Ecol. Man., 259, 698-709, 2010.

Luino, F.: Sequence of instability processes triggered by heavy rainfall in the northern Italy, Geomorphology, 66, 13-39, 2005.

Pardini, G., Gispert, M., and Dunjo, M.: Distribution patterns of soil properties in a rural Mediterranean area in Northeastern Spain, Mount. Res. Develop., 1, 44-51, 2004.

Rhoades, J. D.: Cation exchange capacity, in: Methods of soil analysis, Part 2, edited by: Page, A. L., Miller, R. H., and Keeney, D. R., Agron. Monogr. 9, Am. Soc. Agron., Madison, WI, USA, 149-157, 1982.

Sanchez-Maranon, M., Sorano, M., Delgado, G., and Delgado, R.: Soil quality in Mediterranean mountain environments: effects of land use change, Soil Sci. Soc. Am. J., 66, 948-958, 2002.
Seybold, C. A., Herrick, J. E., and Brejda, J. J.: Soil resilience: a fundamental component of soil quality, Soil Sci., 164, 224-234, 1999.

Seybold, C. A., Elrashidi, M. A., and Engel, R. J.: Linear regression models to estimate soil liquid limit and plasticity index from basic soil properties, Soil Sci., 173, 25-34, 2008.

Shukla, M. K., Lal, R., and Ebinger, M.: Determining soil quality indicators by factor analysis, Soil Till. Res., 87, 194-204, 2006.

S.I.S.S.: Metodi di analisi chimica del suolo, Franco Angeli, Milano, Italia, 2000.

Soil Survey Staff: Soil taxonomy, Tenth Edition, USDA, Washington DC, USA, 2006.

Stanchi, S., Bonifacio, E., and Zanini, E.: Mass-size fractal dimension of primary and aggregated particles and soil profile development, Soil Sci., 173, 87-95, 2008 a.

Stanchi, S., Freppaz, M., Oberto, E., Caimi, A., and Zanini, E.: Plastic and liquid limits in Alpine soils: methods of measurement and relations with soil properties, in: Advances in Geoecology, edited by: Dazzi, C. and Costantini, E., 39, 594-604, 2008 b.

Stanchi, S., Oberto, E., Freppaz, M., and Zanini, E.: Linear regression models for liquid and plastic limit estimation in Alpine soils, Agrochimica, 5, 322-338, 2009.

Turconi, L., De, S. K., Tropeano, D., and Savio, G.: Slope failure and related processes in the Mt. Rocciamelone area (Cenischia Valley, Western Italian Alps), Geomorphology, 114, 115-128, 2010.

Tyler, S. W. and Wheatcraft, S. W.: Fractal scaling of soil particlesize distributions: analysis and limitations, Soil Sci. Soc. Am. J., 56, 362-369, 1992.

Zanini, E., Bonifacio, E., Albertson, J. D., and Nielsen, D. R.: Topsoil aggregate breakdown under water-saturated conditions, Soil Sci., 163, 288-298, 1998. 